\title{
Dendroecological study of Pinus halepensis and Pinus pinea in northeast coastal dunes in Tunisia according to distance from the shoreline and dieback intensity
}

\author{
Beya Bachtobji Bouachir ${ }^{\mathrm{a}, \mathrm{b}, *}$, Ali Khorchani ${ }^{\mathrm{b}}$, Frédéric Guibal ${ }^{\mathrm{c}}$, Mohamed Hédi El Aouni ${ }^{\mathrm{a}}$, \\ Abdelhamid Khaldi ${ }^{\mathrm{b}}$ \\ a University of Carthage, Faculty of Sciences, Bizerte, (FSB), 7021, Zarzouna, Tunisia \\ b National Research Institute of Rural Engineering Water and Forest (INRGREF) Rue Hédi Karray El Menzeh IV, 1004 Tunis, BP Ariana, 2080 Tunisia \\ ${ }^{\mathrm{c}}$ Mediterranean Institute of Biodiversity and Ecology (IMBE), Aix-Marseille Univ, CNRS 7263, IRD, Avignon Univ, Europôle Méditerranéen Arbois, Bât. Villemin, BP 80, \\ 13545 Aix-en-Provence Cedex 4, France
}

\begin{abstract}
A B S T R A C T
Growth decline is a widespread phenomenon on sandy coasts throughout the Mediterranean region. In the northeastern pine coastal woodland of Tunisia, Pinus pinea and Pinus halepensis stands originally afforested to stabilize sand dunes are often damaged. Our objective was to estimate the effect of distance from the shoreline on ring- width variation of two pine species, Pinus pinea and Pinus halepensis located in the Remel and Menzel Belgacem coastal forest land. 15 to 30 trees of each species were selected based on three dieback levels (low, moderate and severe canopy damage). The results of dendroecological analysis show a significant reduction in the mean growth of trees growing near the shoreline for both species. Most stands show a positive correlation with precipitation between October of the previous year to April of the current year. The number of months, when precipitation is correlated positively with growth, is always lower for trees growing near the shoreline than for trees growing in distant stands. However, when the maximum temperature is correlated negatively with growth, the number of months is always higher for trees growing near the shoreline (2 months) than for trees those in distant stands ( 1 month). Moreover, there was an increased number of missing rings in the 1980s but only in those trees growing near the shoreline and their frequency was only statistically significant for Pinus pinea in the two forest sites. The severity of canopy damage due to being close to the shoreline negatively influenced the growth of both species and could threaten their survival in these areas.
\end{abstract}

\section{Introduction}

Forests, which cover about 30 percent of the world's land surface (FAO, 2006), are being rapidly and directly impacted in many areas by human expansion. Less evident are the pervasive effects of ongoing climatic changes on the condition and status of forests around the world. Increased greenhouse gas emissions are now widely acknowledged by the scientific community as a major cause of the recent rise in global mean temperature and changes in the world's hydrological cycle (IPCC, 2007). Understanding and predicting the consequences of these climatic changes on ecosystems is one of the greatest challenges for scientists, and forecasting the impacts on forests is particularly important (Boisvenue and Running, 2006; Bonan, 2008). Of these impacts on forests, tree dieback is a serious phenomenon on a local, regional and national level (Allen et al., 2010). This phenomenon alters the external appearance of the tree due to organ mortality, reducing the quality and quantity of foliage, and may cause stunted growth or even death in some trees (Delatour, 1990). This dieback phenomenon is either caused by pathogens, parasites or conditions like acid rain and drought (Allen, 2009).

Examples of drought and heat-related forest stress and dieback are being documented by all forested continents, making it possible to begin to see global phenomena. Two of the nine tipping points for major climate changes forecast for the next century are directly related to forest dieback (IPCC, 2014). Examples of dieback have been particularly well documented in southern Europe (Breda et al., 2006 and Bigler et al., 2006) and in the temperate and boreal forests of western North America, where background mortality rates have increased rapidly in the past few decades (van Mantgem et al., 2009). The common causal factor in these examples is elevated temperatures and/or water

\footnotetext{
* Corresponding author at: Faculty of Sciences of Bizerte, Department of Biology, 7021 Zarzouna, Bizerte, Tunisia

E-mail address: beyabachtobjii@gmail.com (B. Bachtobji Bouachir).
} 


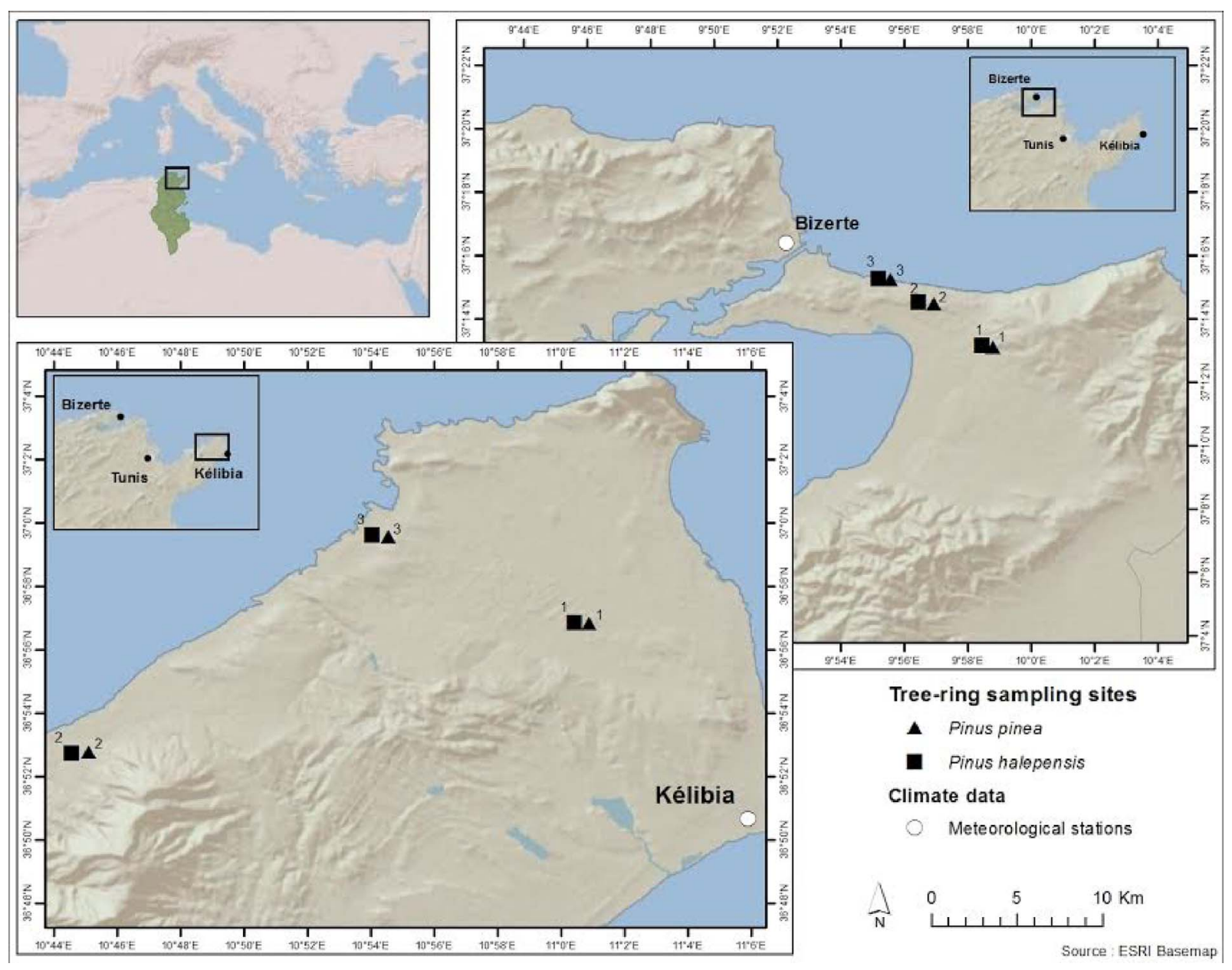

Fig. 1. Location of studied stands of Pinus halepensis and Pinus pinea, Northeast Tunisia.

stress. Recent extreme drought in North Africa (Touchan et al., 2008) has been linked to severe mortality of Atlas cedar (Cedrus atlantica) from Morocco to Algeria (El Abidine, 2003; Bentouati, 2008). Disturbing events have occurred in some forest areas in Tunisia over the last few years (Ben Jamaa et al., 2005, 2006a), raising a number of issues including the effects of drought and global warming (Ben Jamaa et al., 2006b; El Khorchani et al., 2013). Sudden and widespread mortality struck cork oak forests in Tunisia in the late 80s and early 90 s after three years of consecutive drought, affecting more than $20 \%$ of the trees in different cork oak forests (Hasnaoui et al., 2005). The same dieback phenomenon was observed between 2000 and 2003 in Aleppo pine forests in a semiarid bioclimate (Aloui, 2010).

One of the most vulnerable areas to climate change is the coast where about $30 \%$ of the entire coastline is affected by erosion (EEA, 2006). According to commonly accepted models of coastal dynamics (Bruun, 1988; Davidson-Arnott, 2005), an increase in coastal erosion should therefore be expected in the future together with an increase in vulnerability of the coastal ecosystem (IPCC, 2007). Tree dieback along the coast is due to a combination of factors unfavorable to tree growth such as drought, storms, and nutritional problems which lead to overall weakening of the tree and possible death (Garrec, 1994). Moreover, pollution from urbanization, industry, maritime traffic and agriculture converge in coastal waters. This ecosystem degradation directly affects vegetation under stress and demonstrates a rupture in forest management. Since the 80 s, considerable damage has been observed in the maritime pine forests of northern Tunisia, in Bizerte (forests of M'hibes and Rimel) and Tabarka (Sidi Badr forests), following the attack of the insect Tomicus piniperda L. (Ben Jamaa et al., 2000). According to a dendroclimatological study of the impact of drought on the growth of three pine species in Tunisia (maritime pine, stone pine and Aleppo pine), the number of dry years and observably narrower rings increased from 1978 to 2001 compared to the period between 1954 and 1977 (El Khorchani et al., 2006). Deterioration of coastal vegetation in the north of Tunisia is also related to the presence of several pollutants in the marine spray such as anionic surfactants and hydrocarbons (El Ayeb et al., 2004). The acceleration of climate change, extreme climatic events (storms, heat, frost, drought and excess water), anthropogenic changes in land use, and pollution are all factors which can contribute directly or indirectly, alone or in interaction, to the explosion of cases of ecosystem dysfunction. Sustainable and responsible management therefore requires new adaptation strategies. These may include assessing forest vulnerability to climate change, reviewing forest use expectations, identifying research and education needs, developing forest policies to facilitate and anticipate adaptation and maintaining the health and vitality of forest ecosystems (Spittlehouse, 2005). Knowing the extent of the territory affected by dieback will contribute greatly to the decision-making process concerning this crisis. For example, some species currently widely used for reforestation of coastal dunes in Tunisia may be restricted in the future and replaced by other species more resistant to drought, or their silvicultural management techniques may be revised in order to adapt to climate and territorial changes.

Two of the main species used to reforest Mediterranean dune ecosystems are Pinus pinea and Pinus halepensis. These pine species have to survive in hard environmental conditions with constant exposure to threatening marine spray and water stress conditions (Garrec, 1994). In southeast Spain, Raventós et al. (2001) showed that Pinus pinea and Pinus halepensis are highly sensitive to exposure both to sea spray and to surfactants in marine aerosols, as reported in other parts of the 
Mediterranean coast of Spain (Diamentapolos et al., 2000). Reduced growth of Pinus pinea along the Tyrrhenian coast of Tuscany (Italy) is due to the crown's greater exposure to salty winds and surfactants and the increased salinity of the water table (Raddi et al., 2009).

Remel and Menel Belgacem forests, pine coastal woodlands of Tunisia, are good examples for studying the vulnerability of these two species under severe conditions of marine spray and drought. In these areas located along the northern coastal dunes, Pinus pinea and Pinus halepensis have clearly suffered canopy damage due to the proximity of the shoreline. In this study, a dendroecological approach was used to estimate the effect of distance from the shoreline on two pine species, Pinus pinea and Pinus halepensis, growing in two forest sites in northeast Tunisia.

\section{Material and methods}

\subsection{Study area}

The study was carried out in northeastern Tunisia (Fig. 1) on two coastal Pinus pinea and Pinus halepensis planted forests. The first site is located in Remel Forest $\left(37^{\circ} 11^{\prime} \mathrm{N}, 10^{\circ} 04^{\prime} \mathrm{E}\right)$ in the region of Bizerte, and the second is in Menzel Belgacem Forest ( $\left.36^{\circ} 57^{\prime} \mathrm{N}, 10^{\circ} 57^{\prime} \mathrm{E}\right)$ in Kelibia in the Cap Bon region. These forest sites have a sandy dune ecosystem and belong to the Mediterranean subhumid bioclimate. The mean annual rainfall in the Bizerte site is $656 \mathrm{~mm}$, concentrated mainly in the winter. In Kelibia, the mean annual rainfall is $550 \mathrm{~mm}$, mostly falling in autumn. Annual temperature varies from $7{ }^{\circ} \mathrm{C}$ (January) to $32{ }^{\circ} \mathrm{C}$ (August) in Bizerte and from $8{ }^{\circ} \mathrm{C}$ (January) to $31^{\circ} \mathrm{C}$ (August) in Kelibia. Northwestern winds with a mean annual speed of $3.8 \mathrm{~m} \mathrm{~s}^{-1}$ and $3 \mathrm{~m} \mathrm{~s}^{-1}$ are most dominant in Bizerte and Kelibia, respectively.

The sand dunes of both sites have been afforested with species such as Acacia sp, Eucalyptus sp., Pinus halepensis, Pinus pinea and Pinus pinaster since the 1900s to fix the dunes along the coastal area.

\subsection{Collection of data and measurements}

\subsubsection{Structural data}

From 2010-2015, 12 plantation stands of Pinus pinea and Pinus halepensis with different environmental conditions were studied in the Remel and Menzel Belgacem forests. For each species in each forest site, three stands were sampled along a latitudinal transect according to distance from the shoreline. Characterization of the stands was analyzed by spiral plots according to the protocol used by the Department of Forest Health in France for determining tree dieback classes (Office National des Forêts, 2010). The center of the plot being fixed by the sampling plan, the first tree is the closest to the center of the plot and the following trees are chosen step by step in a spiral to reach the defined number (recommended: 20 trees within a maximum radius of $40 \mathrm{~m}$ ). The method consists of estimating leaf deficit at the crown level of each sampled tree. Leaf deficit includes the absence of needles due to drop; twig drop, dried by wind or insects; reduced growth resulting in fewer branches or a smaller individual leaf area due to the phenomenon of microphylla or the impact of insects or foliar diseases. To assess leaf deficit, the appearance of the crown is described by assigning a dieback index. The dieback index in $\%$ is calculated by observing the foliar deficit in the crown. In order to limit the interference between phytosanitary problems and symptoms related to competition or lack of light, only dominant or codominant trees were sampled. For each plot, tree density (trees ha ${ }^{-1}$ ), diameter at breast height (DBH, $\left.\mathrm{cm}\right)$, height $(\mathrm{m})$, height and crown diameter (m) for 20 trees were measured. Table 1 shows the characteristics of each stand based on the distance from the shoreline and dieback intensity.

\subsubsection{Dendroecological data}

For the dendroecological study, 15-30 trees were selected in each plot and 2-3 cores were extracted from each tree. Cores were collected at breast height $(1.30 \mathrm{~m})$ with a Swedish increment borer $5 \mathrm{~mm}$ in diameter. All cores were placed on wooden supports and specimen details such as site name, sample number and collection date were recorded for identification purposes. These cores were polished using a sanding machine with progressively finer sandpaper $(\times 100 \times 180)$ to obtain a smooth surface.

Cores were visually crossdated with each other by using regional pointer years (missing rings, false rings and narrow rings). The computer program COFECHA (Holmes 1983) was run to examine the statistical quality of the association between the aligned series. COFECHA standardizes raw ring width series and subsequently evaluates the statistical significance of the correlation of each whole series and series segment with a master series by using the Pearson coefficient (r-value) (Grissino-Mayer 2001). The segment length of 20 years lagged by 10 years was used for this study. Placement of missing rings was checked by direct comparison of the wood samples under a microscope and by COFECHA. The frequency of missing rings in each series was calculated for each calendar year. Ring widths were measured from bark to pith with a precision of $0.01 \mathrm{~mm}$ using the TSAP Win software and LINTAB ${ }^{\circ}$ (Rinn, 2003) measuring table in the National Institute for Research in Rural Engineering, Water and Forests of Tunis and in the Mediterranean Institute of Biodiversity and Ecology of Marseille. Ring width series were standardized using the ARSTAN program (Cook and Peters, 1981; Holmes et al., 1986). The long-term trend was removed from each raw chronology by fitting a curve and calculating an index defined as measured ring width for each year divided by the curve-fit value. This made it possible to remove age trend, non-climatic factors and the effects of stand dynamics (Cook and Kairiukstis, 1990). Thus, we applied a double detrending with a negative exponential curve or linear regression equation in the first step and a cubic smoothing spline in the second step.

Finally, for each stand, a non-autoregressive chronology was computed by a technique known as "bi-weight robust estimate of the mean" designed to reduce the influence of isolated outlier values (Cook, 1985).

The ARSTAN program produces three chronologies: standard, residual and arstan. Residual chronology uses autoregressive modeling to remove any signal in the data that carries over from year to year and that may cause an unrealistic increase in the correlation with climate variables (Henderson and Grissino-Mayer, 2009). Because residual chronology showed the strongest and most interpretable relationship, we selected it to model the tree growth to climate relationship (Parker et al., 2014).

Dendrochronological variables calculated by ARSTAN and expressing the climate signal such as mean sensitivity, standard deviation and autocorrelation are good indicators for tree-ring to climate relationship studies (Fritts, 1976) (Table 2).

\subsubsection{Climate data}

To establish tree growth relationships to climate, reliable climate data close to the sampling sites are crucial. Available climate data from several meteorological stations around the sampling sites were scrutinized for their quality assessments especially in terms of homogeneity, duration and continuity of data. The monthly average of maximal and minimal temperature and monthly total precipitation data from 1950 to 2014 were collected from the two nearest meteorological stations: Bizerte $\left(37^{\circ} 15^{\prime} \mathrm{N}, 09^{\circ} 48^{\prime} \mathrm{E}\right)$ and Kelibia $\left(36^{\circ} 51^{\prime} \mathrm{N}, 11^{\circ} 05^{\prime} \mathrm{E}\right)$.

\subsubsection{Tree-growth relationship to climate}

A response function analysis (Fritts, 1976) and bootstrap technique (Guiot, 1991) were used to determine the relationship between tree rings and climate with 3PBase software (Guiot and Goeury, 1996). A response function analysis is a multiple regression technique after extracting the main components of monthly climatic data (predictors) to determine the significant climatic variable influencing ring width (predictants). With the bootstrap technique, 200 iterations were done to obtain 200 sets of regression coefficients, 200 multiple calibrations and 
Table 1

Characteristics of each stand based on the distance from the shoreline and dieback intensity.

\begin{tabular}{|c|c|c|c|c|c|c|}
\hline Region & Site name & Stand name & Distance from the shoreline $(\mathrm{km})$ & Dieback index in $\%$ (dieback intensity) & Tree density (trees ha ${ }^{-1}$ ) & Age (year) \\
\hline BIZERTE & RIMEL & BZPH1 & 3.154 & 12.66 (Low) & 668 & 54 \\
\hline BIZERTE & RIMEL & BZPH2 & 1.155 & 26.27 (moderate) & 684 & 52 \\
\hline BIZERTE & RIMEL & BZPH3 & 0.105 & 76.26 (very strong) & 660 & 64 \\
\hline BIZERTE & RIMEL & BZPP1 & 3.187 & 13.25 (Low) & 557 & 64 \\
\hline BIZERTE & RIMEL & BZPP2 & 1.263 & 26.31 (moderate) & 716 & 90 \\
\hline BIZERTE & RIMEL & BZPP3 & 0.123 & 76.25 (very strong) & 724 & 70 \\
\hline KELIBIA & MEZEL BELGACEM & KBPH1 & 7.464 & 14.65 (Low) & 636 & 69 \\
\hline KELIBIA & MEZEL BELGACEM & КBPH2 & 1.725 & 24.93 (moderate) & 652 & 52 \\
\hline KELIBIA & MEZEL BELGACEM & КВРН3 & 0.727 & 76.27 (very strong) & 684 & 64 \\
\hline KELIBIA & MEZEL BELGACEM & КBPP1 & 7.619 & 9.53 (Low) & 605 & 62 \\
\hline KELIBIA & MEZEL BELGACEM & КBPР2 & 1.635 & 27.67 (moderate) & 668 & 50 \\
\hline KELIBIA & MEZEL BELGACEM & КВРР3 & 0.680 & 76.43 (very strong) & 700 & 65 \\
\hline
\end{tabular}

200 verification correlation coefficients. In tree-ring analysis, this method offers the advantage of avoiding errors caused by colinearity among variables and provides a more realistic estimate of tree response to climate. Whether for regression coefficients or for the overall significance of the response function, the different calculated ratios (mean multiple correlation coefficient or mean regression coefficient divided by standard deviation) give an approximate value of the $t$ student coefficient (Gadbin-Henry, 1994).

Analyses were done between residual tree ring chronologies and monthly climatic variables (precipitation, maximal and minimal temperature). These climatic variables were organized according to the biological calendar for the Mediterranean region from October of the previous year to September of the current year (Serre, 1973).

\subsection{Data analysis}

Mean and standard deviation were calculated for each stand parameter (Mean Height, DBH, Height of the crown, Diameter of the crown and Mean ring width). For missing rings, frequency was calculated for each stand in ten-year increments from 1955 until 2014. An analysis of variance (ANOVA) under SAS software (9.1) was applied with distance from the shoreline as a source of variation to five stand parameters. To test the effect of distance from the shoreline and the effect of time period on missing rings, a two-way analysis of variance (ANOVA) was used. The main effects of distance from the shoreline and time periods were tested for statistical differences using the Newman-Keuls test.

\section{Results}

\subsection{Crossdating}

From the available samples, 627 ring width series from 12 stands were crossdated successfully. Statistics for each site are listed in Table 3. Using regional pointer years (missing rings, false rings and narrow ring) made crossdating much easier. Mean series inter-correlations were reasonable and gave high values for all sites (0.709-0.980). The number of 20-ring segments with possible problems was low. Comparing site composite skeleton plots and each series with the master series showed clear similarities in growth patterns. However, correlation coefficients for some segments were not statistically significant at $99 \%$ but no negative correlation was detected in any segment. The critical correlation coefficient at the $99 \%$ confidence level associated with the selected segment length (20 years) was 0.515 . For each species at each site, localizing missing rings (Table 3 ) and false rings (Fig. 2) in all measurement series certified good crossdating.

\subsection{Stand characteristics}

The results of the analysis of variance (ANOVA) revealed a significant difference in the structural measurement between stands of each species in each forest site. Along the transect, the closer the distance to the shoreline, the greater the decrease in diameter at breast height, tree height, height and crown diameter (Table 4). When comparing the three stands in each transect for each species, trees growing near the shoreline were more sensitive and smaller in radial growth on average. Stands with the highest percentage of dieback index always showed the lowest growth and structural values regardless of stand age. BZPP2 is the oldest stand (90 years) for Pinus pinea transect in Bizerte; however, the lowest growth and structural values were recorded in BZPP3 (70 years). KBPH1 is the oldest stand (69 years) for Pinus halepensis transect in Kelibia; however, the lowest growth and structural values were recorded in KBPH3 (64 years).

\subsection{Missing and false rings}

Table 3 shows that missing rings were observed only in stands near the shoreline for both species in both sites. The number of missing rings was higher for Pinus pinea than Pinus halepensis. The number of series

Table 2

Summary statistics from computer program ARSTAN.

\begin{tabular}{|c|c|c|c|c|c|c|c|}
\hline Station & Time Span & Mean sensitivity & Standard diviation & Skewness & Kurtosis & Autocorrelation 1 (RESID) & Autocorrelation 1 (STNDRD) \\
\hline BZPH1 & $1960-2014$ & 0.29 & 0.25 & 0.010 & -0.172 & -0.044 & 0.09 \\
\hline BZPH2 & $1962-2014$ & 0.29 & 0.24 & -0.248 & 0.412 & -0.082 & 0.12 \\
\hline BZPH3 & $1950-2014$ & 0.31 & 0.28 & 0.129 & 0.325 & -0.009 & 0.10 \\
\hline BZPP1 & $1950-2014$ & 0.40 & 0.36 & 0.372 & -0.380 & 0.006 & 0.01 \\
\hline BZPP2 & 1924-2014 & 0.38 & 0.36 & 0.585 & 1.305 & -0.31 & 0.27 \\
\hline BZPP3 & $1944-2014$ & 0.45 & 0.40 & -0.265 & -0.06 & 0.04 & 0.24 \\
\hline КВРН1 & $1945-2014$ & 0.41 & 0.36 & 1.023 & 1.415 & -0.058 & 0.02 \\
\hline КВРН2 & $1962-2014$ & 0.43 & 0.37 & 0.334 & 0.379 & -0.035 & 0.23 \\
\hline КВРH3 & $1950-2014$ & 0.59 & 0.48 & 0.570 & 0.850 & -0.010 & 0.07 \\
\hline КВРP1 & 1950-2012 & 0.43 & 0.39 & 0.887 & 0.423 & -0.019 & 0.08 \\
\hline КВРР2 & $1962-2012$ & 0.45 & 0.37 & 0.036 & -0.214 & -0.029 & 0.17 \\
\hline КВРР3 & $1945-2010$ & 0.47 & 0.44 & -0.133 & 0.499 & 0.008 & 0.25 \\
\hline
\end{tabular}


Table 3

COFECHA results and ring width statistics per site.

\begin{tabular}{|c|c|c|c|c|c|c|c|c|c|c|c|c|}
\hline & KBPH1 & KBPH22 & КВРН3 & KBPP1 & КBPP2 & КВРР3 & BZPH1 & BZPH2 & BZPH3 & BZPP1 & BZPP2 & BZPP3 \\
\hline No. of dated series & 30 & 49 & 30 & 29 & 58 & 84 & 30 & 30 & 74 & 30 & 93 & 90 \\
\hline Time span & 65 & 54 & 50 & 60 & 52 & 60 & 55 & 53 & 65 & 65 & 65 & 65 \\
\hline Mean series inter-correlation & 0.888 & 0.922 & 0.959 & 0.915 & 0.908 & 0.864 & 0.980 & 0.709 & 0.802 & 0.964 & 0.819 & 0.845 \\
\hline Segments with possible problems & 0 & 0 & 0 & 0 & 0 & 3 & 0 & 5 & 7 & 0 & 3 & 5 \\
\hline No. Of missing rings & 0 & 0 & 36 & 0 & 0 & 291 & 0 & 0 & 17 & 0 & 0 & 240 \\
\hline \multicolumn{13}{|l|}{ No. of series with missing ring } \\
\hline 1967 & & & 5 & & & 15 & & & & & & 17 \\
\hline 1968 & & & & & & 3 & & & & & & \\
\hline 1981 & & & 1 & & & 15 & & & & & & 10 \\
\hline 1988 & & & 8 & & & 67 & & & 2 & & & 70 \\
\hline 1989 & & & & & & 41 & & & 1 & & & 42 \\
\hline 1990 & & & & & & 10 & & & & & & \\
\hline 1995 & & & 4 & & & 9 & & & 6 & & & 17 \\
\hline 1998 & & & & & & 7 & & & & & & \\
\hline 1999 & & & 2 & & & 37 & & & & & & 1 \\
\hline 2001 & & & & & & 2 & & & & & & \\
\hline 2002 & & & 13 & & & 78 & & & 8 & & & 59 \\
\hline 2005 & & & & & & & & & & & & 6 \\
\hline 2006 & & & 3 & & & & & & & & & \\
\hline 2007 & & & & & & & & & & & & 4 \\
\hline 2008 & & & & & & 7 & & & & & & 14 \\
\hline
\end{tabular}

Segments with possible problems is the number of 20-ring segments where the correlation with the master series is less than 0.515 .

with missing rings could indicate the years when there were more affected trees with missing rings. The results of crossdating showed that in the years 1988-1989 and 2002, there were more affected trees with missing rings.

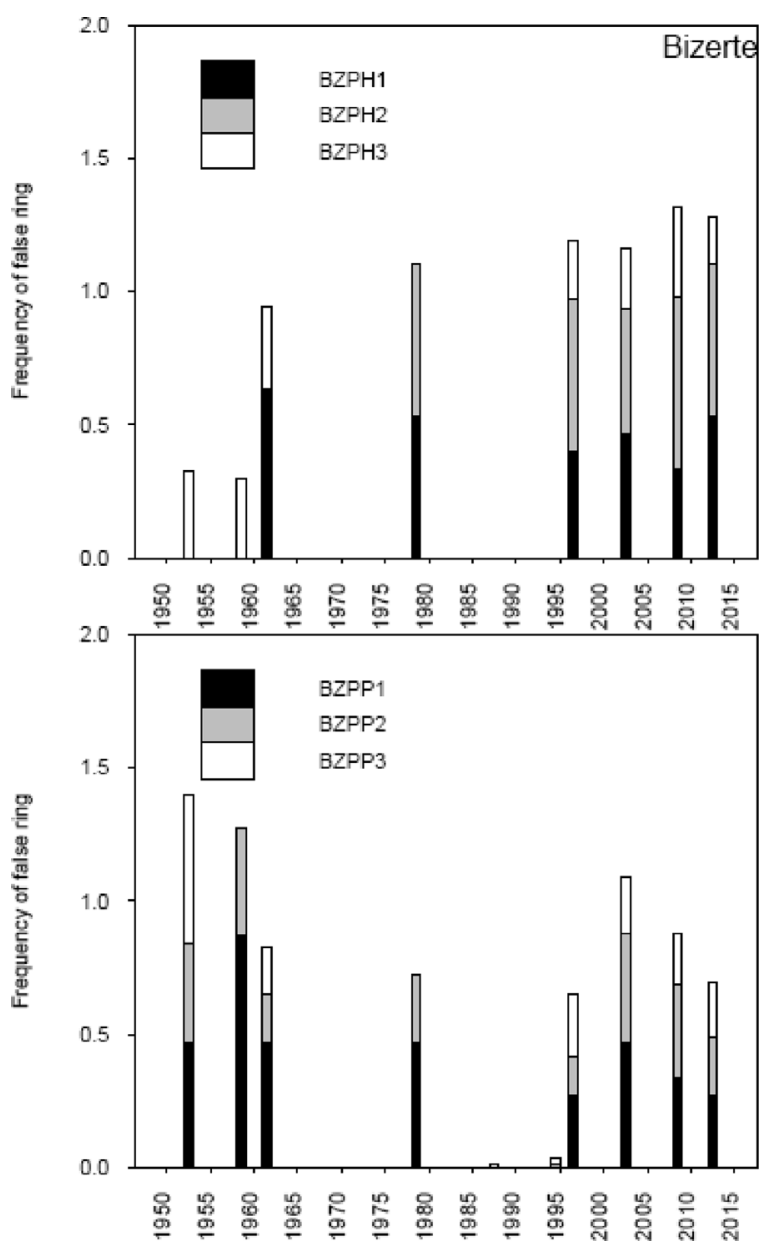

Fig. 2 shows the distribution of false rings by species and site. At each site, there was a similarity in the distribution of false rings. However, this distribution was often lacking in some stands.

Table 5 shows the statistics on missing rings for the period

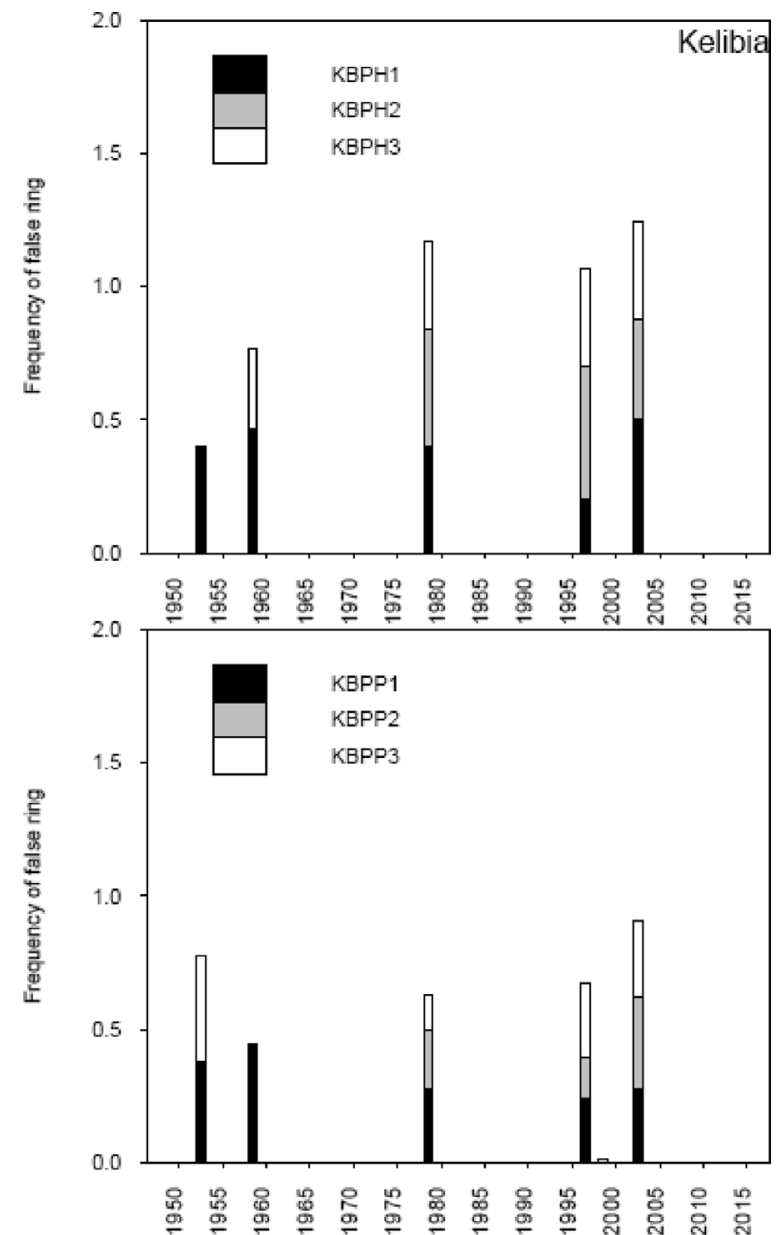

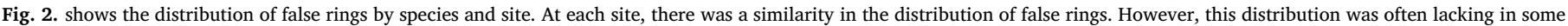
stands. 
Table 4

Analysis of variance (ANOVA) with distance from the shoreline as source of variation to 5 stand parameters.

\begin{tabular}{|c|c|c|c|c|c|c|}
\hline Chronology name & Common Intervals & DBH $(\mathrm{cm})$ & $\mathrm{H}(\mathrm{m})$ & Height of the crown (m) & Diameter of the crown (m) & Mean radial growth $(1 / 100 \mathrm{~mm})$ \\
\hline BZPH1 & $1962-2014$ & $33.22 \pm 6.03 \mathrm{a}$ & $19.96 \pm 1.41 \mathrm{a}$ & $5.81 \pm 1.06 \mathrm{a}$ & $8.07 \pm 0.60 \mathrm{a}$ & $379.03 \pm 242.90 \mathrm{a}$ \\
\hline BZPH2 & $1962-2014$ & $32.30 \pm 4.42 \mathrm{a}$ & $17.52 \pm 0.89 \mathrm{~b}$ & $4.65 \pm 0.52 \mathrm{~b}$ & $7.18 \pm 0.99 \mathrm{~b}$ & $321.12 \pm 222.96 \mathrm{~b}$ \\
\hline BZPH3 & $1962-2014$ & $25.41 \pm 6.50 \mathrm{~b}$ & $12.86 \pm 1.03 \mathrm{c}$ & $1.90 \pm 0.31 \mathrm{c}$ & $3.02 \pm 0.75 c$ & $72.57 \pm 37.95 \mathrm{c}$ \\
\hline BZPP1 & 1950-2014 & $33.45 \pm 5.67 \mathrm{a}$ & $20.17 \pm 0.89 a$ & $5 \pm 0.96 \mathrm{a}$ & $8.01 \pm 0.32 \mathrm{a}$ & $321.12 \pm 317 \mathrm{a}$ \\
\hline BZPP2 & 1950-2014 & $32.05 \pm 5.29 \mathrm{a}$ & $17.83 \pm 0.82 \mathrm{~b}$ & $4.43 \pm 0.46 \mathrm{~b}$ & $7.44 \pm 0.95 b$ & $122.68 \pm 70.71 \mathrm{~b}$ \\
\hline BZPP3 & $1950-2014$ & $25.47 \pm 4.24 \mathrm{~b}$ & $13.44 \pm 0.62 \mathrm{c}$ & $1.82 \pm 0.20 \mathrm{c}$ & $2.94 \pm 0.40 c$ & $89.57 \pm 107.85 c$ \\
\hline КВРН1 & $1961-2014$ & $34.71 \pm 4.34 \mathrm{a}$ & $20.13 \pm 1.07 \mathrm{a}$ & $4.83 \pm 0.66 \mathrm{a}$ & $7.44 \pm 0.63 \mathrm{a}$ & $160.37 \pm 107.06 \mathrm{a}$ \\
\hline КВРН2 & 1961-2014 & $26.03 \pm 4.24 \mathrm{~b}$ & $15.05 \pm 1.18 \mathrm{~b}$ & $3.61 \pm 0.59 \mathrm{~b}$ & $6.52 \pm 0.74 \mathrm{~b}$ & $167.87 \pm 98.34 \mathrm{a}$ \\
\hline КBPH3 & $1961-2014$ & $21.38 \pm 5.05 c$ & $10.08 \pm 1.42 \mathrm{c}$ & $2.25 \pm 0.32 \mathrm{c}$ & $3.22 \pm 0.65 c$ & $104.95 \pm 82.07 b$ \\
\hline KBPP1 & $1961-2010$ & $36.07 \pm 4.11 \mathrm{a}$ & $20.66 \pm 1.53 \mathrm{a}$ & $5.45 \pm 0.49 \mathrm{a}$ & $8.74 \pm 1.15 \mathrm{a}$ & $109.38 \pm 78.28 \mathrm{a}$ \\
\hline КВРP2 & $1961-2010$ & $25.95 \pm 4.16 b$ & $14.89 \pm 1.14 \mathrm{~b}$ & $3.60 \pm 0.56 \mathrm{~b}$ & $5.87 \pm 0.87 b$ & $217.12 \pm 148.92 \mathrm{~b}$ \\
\hline КВРР3 & $1961-2010$ & $21.84 \pm 3.82 c$ & $11.30 \pm 1.06 \mathrm{c}$ & $2.28 \pm 0.33 c$ & $4.45 \pm 0.78 c$ & $49.37 \pm 33.05 c$ \\
\hline
\end{tabular}

Table 5

Mean number of missing rings in Pinus pinea and Pinus halepensis per decade for various types of canopy damage.

\begin{tabular}{|c|c|c|c|c|c|c|}
\hline Site & 1955-1964 & 1965-1974 & 1975-1984 & 1985-1994 & 1995-2004 & 2005-2014 \\
\hline BZPH1 & $0 \mathrm{ab}$ & $0 \mathrm{ab}$ & $0 \mathrm{ab}$ & $0 \mathrm{ab}$ & $0 \mathrm{ab}$ & $0 \mathrm{ab}$ \\
\hline BZPH2 & $0 \mathrm{ab}$ & $0 \mathrm{ab}$ & $0 \mathrm{ab}$ & $0 \mathrm{ab}$ & $0 \mathrm{ab}$ & $0 \mathrm{ab}$ \\
\hline BZPH3 & $\mathrm{Ob}$ & $\mathrm{Ob}$ & $\mathrm{ob}$ & $0.40 \mathrm{~b}$ & $1.89 \mathrm{~b}$ & ob \\
\hline BZPP1 & $\mathrm{Ob}$ & $0 \mathrm{~b}$ & $\mathrm{Ob}$ & $\mathrm{Ob}$ & ob & $\mathrm{Ob}$ \\
\hline BZPP2 & $\mathrm{Ob}$ & ob & ob & ob & ob & $\mathrm{Ob}$ \\
\hline BZPP3 & $0 \mathrm{~b}$ & $1.88 \mathrm{~b}$ & $1.11 \mathrm{~b}$ & $12.44 \mathrm{a}$ & $8 a$ & $2 b$ \\
\hline КВРН1 & $0 \mathrm{ab}$ & $0 \mathrm{ab}$ & $0 \mathrm{ab}$ & 0ab & $0 \mathrm{ab}$ & $0 \mathrm{ab}$ \\
\hline КВРН2 & $0 \mathrm{ab}$ & $0 \mathrm{ab}$ & $0 \mathrm{ab}$ & $0 \mathrm{ab}$ & 0ab & 0ab \\
\hline КВРНЗ & $0 \mathrm{ab}$ & $0 \mathrm{ab}$ & $0.33 \mathrm{ab}$ & $2.66 \mathrm{ab}$ & $5.66 \mathrm{ab}$ & $1 \mathrm{ab}$ \\
\hline КВPP1 & $0 \mathrm{ab}$ & $0 \mathrm{ab}$ & 0ab & $0 \mathrm{ab}$ & 0ab & $0 \mathrm{ab}$ \\
\hline КВРP2 & $0 \mathrm{ab}$ & $0 \mathrm{ab}$ & $0 \mathrm{ab}$ & $0 \mathrm{ab}$ & $0 \mathrm{ab}$ & $0 \mathrm{ab}$ \\
\hline КВРР3 & $0 \mathrm{ab}$ & $2.10 \mathrm{ab}$ & $1.97 \mathrm{ab}$ & $15.39 \mathrm{a}$ & $16.71 \mathrm{a}$ & $0.92 \mathrm{ab}$ \\
\hline
\end{tabular}

In the same line the followed figures by the same letter indicate the absence of significant differences to the threshold of $5 \%$.

1955-2014 using a variance analysis. For both species, no missing rings were observed for the first period (1955-1964), but the appearance of missing rings was observed from the period 1965-1974 until 2005-2014 but only for trees growing near the shoreline. In contrast, no missing rings were recorded in trees growing far from the shoreline. Their frequency was only statistically significant for Pinus pinea in the two forest sites for the periods 1985-1994 and 1995-2004.

\subsection{Climatic influence on tree-growth}

The tree-growth to climate relationship of the two pine species in both studied forest sites was illustrated using a response function analysis (Figs. 3 and 4). Only response functions for the combination of maximal temperature and precipitation were significant. The calculated ratios (mean multiple correlation coefficient divided by standard deviation) show that all response functions were significant. The climategrowth relationship showed two types of correlation: positive correlation with precipitation and negative correlation with maximal temperature. The monthly variables significantly correlated with growth varied between stands depending on the species and the distance from the shoreline. Most stands showed positive correlation with precipitation between October of the previous year and April of the current year. Concerning the negative correlation with maximal temperature, difference occurred along the transect, between stands for both species in both forest sites. In the Kelibia forest site, both species growing in stands far from the shoreline showed negative correlation only with the March maximal temperature, while in stands near the shoreline both species showed negative correlations with both March and April maximal temperatures. In the Bizerte forest site, negative correlation with maximal temperature was observed in May for both species growing in stands far from the shoreline, in February and March for the Pinus halepensis stand and in March and May for the Pinus pinea stand near the shoreline.
Fig. 5 shows a mixed graph of missing rings, residual site chronologies, temperature and precipitation based on the results of response function. With this graph, the reason for the increased number of missing rings in the coastal sites can be understood clearly. Dry conditions from October to April and high temperatures from March to April in Kelibia and from February to May in Bizerte seem to be the main climatic elements causing missing rings in both species. In Bizerte, the rainfall deficit was $55 \%$ and $50 \%$ for 1988 and 2002, respectively, and the increase in maximum temperature was $1.3{ }^{\circ} \mathrm{C}$ and $1.4{ }^{\circ} \mathrm{C}$, respectively. In Kelibia, this deficit was $39 \%$ and $45 \%$ and the increase in maximum temperature was $0.67{ }^{\circ} \mathrm{C}$ and $1.67{ }^{\circ} \mathrm{C}$, respectively. Comparisons of site chronologies for each species and site showed clear similarities in growth patterns. Missing rings occurred where rings were usually narrow. This is explained by the fact that, for a year, when a tree shows a missing ring, another tree shows a narrow ring. Missing rings are also included when computing the master series.

\section{Discussion}

Pines are important components of coastline landscapes in North Africa. Pine forests can be found along a coastal strip of this region. Of the Mediterranean pines which occur at low altitude close to the coast, Pinus halepensis, $P$. pinaster and $P$. pinea are the most frequent. $P$. pinea's natural range is difficult to define because it has been planted widely for so long (Barbero et al., 1998). Pine forests play a crucial role in this region in preventing water erosion by decreasing the effect of erosive forces and keeping the soil in place (Mazzoleni et al., 2004). The extensive root system and large crown make the species resistant to strong winds, which is why $P$. pinea has been used to consolidate sand dunes and protect soil from erosion in exposed coastal areas. Moreover, the multi-layered root system makes it possible for mature trees to obtain water from different levels of the soil and from various sources of water: precipitation, soil water and the water table (Frattegiani et al., 1994). 

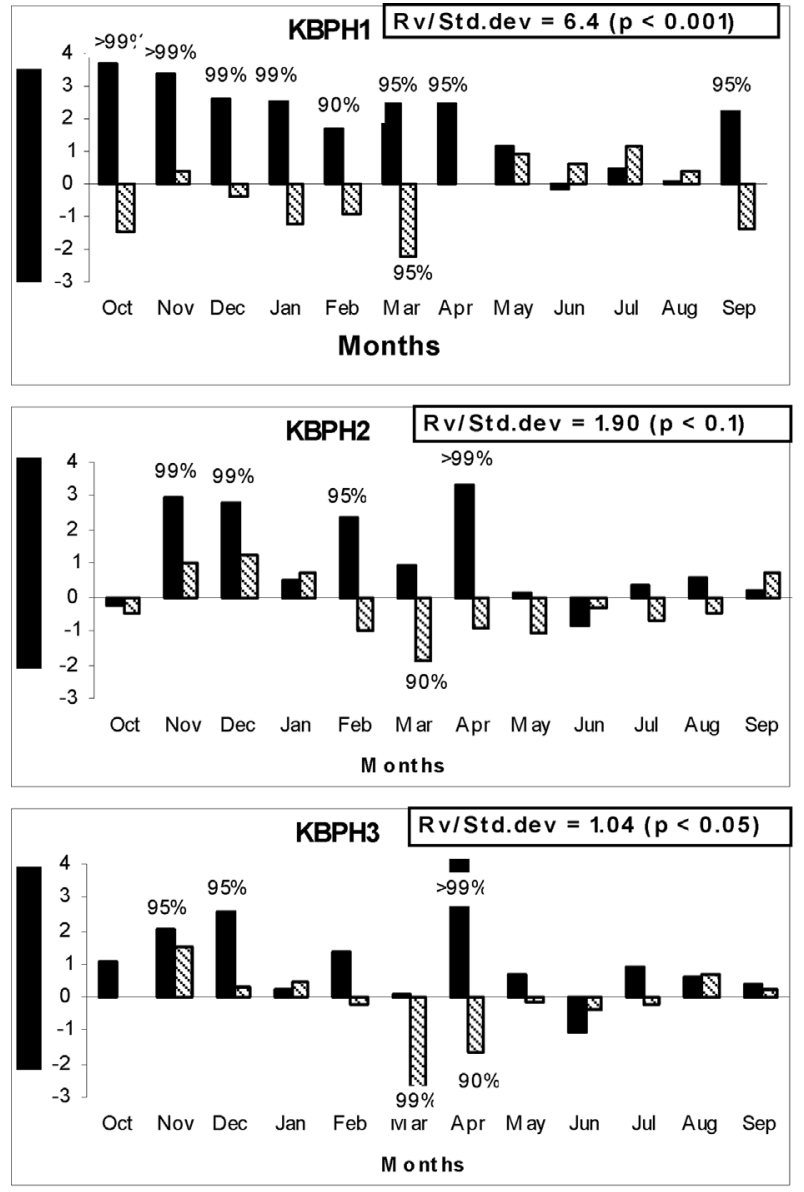

Precipitation

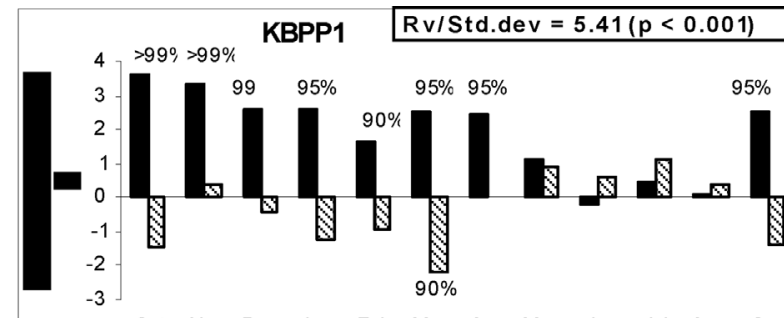

Oct Nov Dec Jan Feb Mar Apr May Jun Jul Aug Sep Months

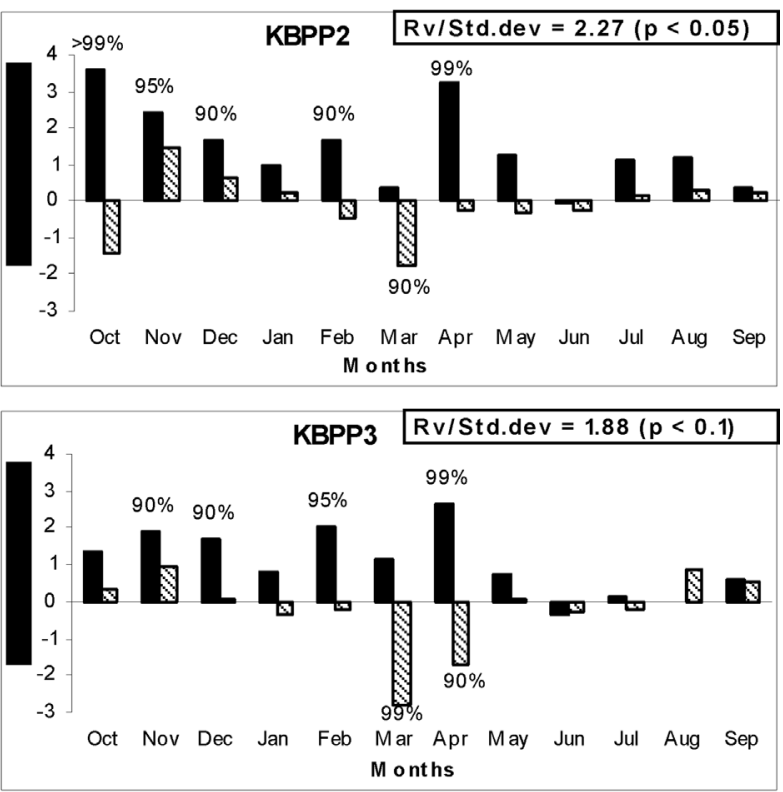

$\mathbf{N}$ Maximum temperature

Fig. 3. Response functions for Pinus halepensis and Pinus pinea in Kelibia with monthly average precipitation and maximal temperature.

In this study, the differences in Pinus halepensis and Pinus pinea stand structure and growth reflect the effect of the distance from shoreline. Stands with the highest percentage of dieback index always showed the lowest growth and structural values regardless of stand age. Tree age should also be taken into consideration as one of the reasons for differences in growth between stands but its effect is masked by that of dieback intensity and remains minor. However, the effect of age could be important during the first years of life, when even-aged stands of Pinus spp. have high radial growth rates. These high rates are only induced by competition from shrubs and understory vegetation because of the light-demanding behavior typical of the pioneer species. However, competition in planted pinewoods is not as strong as in naturally regenerating pines. (Mazza and Manetti, 2013).

The distance from the shoreline influences environmental variables such as mean temperature, water availability, growth period extension, land use, erosion and exposition to sea spray. This characteristic was observed for these species on the Mediterranean coast in Italy (Gellini et al., 1986; Bussotti et al., 1995; Nicolotti et al., 2005; Raddi et al., 2009) and in Spain (Diamantopouolos et al., 2000; Raventos et al., 2001). According to Raddi et al. (2009), growth decline in Pinus pinea on the eroded coastal dunes in Italy may be attributed to greater exposure of the crowns to salty winds and surfactants and increased salinity of the water table. On the other hand, Pinus pinea is highly sensitive to exposure both to sea spray and to surfactants in marine aerosols (Raventos et al., 2001; Rettori et al., 2005). In the Mezel Belgacem forest, El Ayeb et al. (2004) noted increased $\mathrm{Na}^{+}$concentration in leaf tissue when trees were closer to the shoreline $\left(\mathrm{Na}^{+}\right.$increased from 0.54 to $0.62 \%$ in Acacia and from 0.39 to $2.3 \%$ in Eucalyptus). A synergistic effect due to seawater contamination with anionic surfactants was recognized to be the cause of growth decline on the north coast of Tunisia (El Ayeb et al., 2004). Sea-spray containing the surfactants and hydrocarbons had a significant impact on leaves with particular deterioration of the cuticle. Indeed, deleterious effects of $\mathrm{Na}^{+}$and $\mathrm{Cl}^{-}$ions and the pollutants present in the spray on leaf tissue occurred when these substances crossed the cuticular barrier (Bussotti et al., 1997). This phenomenon could explain the reduction of photosynthetic activity in decaying trees and thereafter the growth reduction in trees growing near the shoreline.

The results of this study show that the frequency of missing rings was surprisingly high in Pinus pinea compared to Pinus halepensis. However, in a semiarid Mediterranean site in Spain, Pinus. halepensis was shown to be more sensitive to drought than Pinus pinea (Novak et al., 2011). These results confirm that, with increasingly severe environmental conditions, production of wood may be partly or totally absent. This might be the case for the trees in our study, where the frequency of missing rings has increased since the 1980s and there have been more and more missing rings in those stands nearest the shoreline. Several factors may be the cause of this increase in missing ring frequency. It may be associated with an increase in water stress, which could be of climatic origin (dry years) or edaphic origin (sandy soils of the littoral dunes). However, dry conditions from October to April and high temperature in late winter and spring were found to be the main climatic factors causing missing rings in both species. In a study on the impact of drought on the growth of three tree species in Tunisia (Pinus halepensis Mill., Pinus pinea L., and Pinus pinaster Sol.), El Khorchani et al. (2007) found a correlation between increased drought and the 

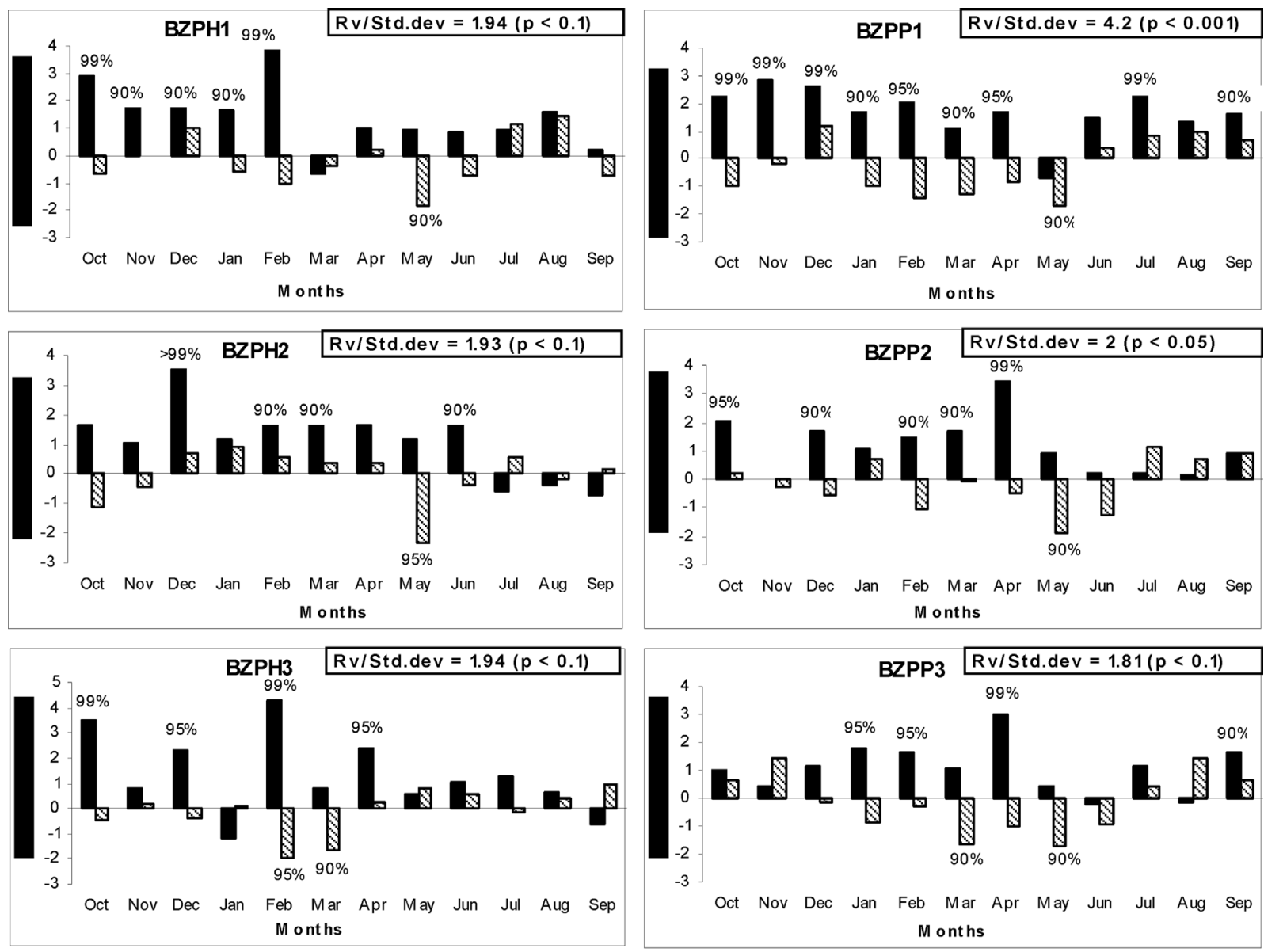

Precipitation $\mathbf{\Delta}$ Maximum temperature

Fig. 4. Response functions for Pinus halepensis and Pinus pinea in Bizerte with monthly average precipitation and maximal temperature.

appearance of narrow rings in the period from 1978 to 2001 compared to the 1954-1977 period. de Luis et al. $(2009,2010)$ showed that the first potential cause of an observed increase of missing rings could be related to increased stress conditions due to rising temperatures and decreased precipitation recorded in Spanish Mediterranean areas since the mid-1970s. Other dendrochronological studies on Pinus pinea and Pinus halepensis from semiarid coastal sand dunes in southeastern Spain have showed a high frequency of missing rings in recent years due to dryness and other disturbance factors such as marine spray (Raventos et al., 2001; Novak et al., 2011).

In addition to climate, other stressors might contribute to the frequency of missing rings. The coastal vegetation in north Tunisia is harmfully affected by chemical components contained in marine spray (El Ayeb et al., 2004). As reported in other parts of the Mediterranean coast in Spain (Raventos et al., 2001) and in Italy (Bussotti et al., 1995), the appearance of missing rings might accompany alteration or death of needles, decreased photosynthetic production and reduced availability of assimilates for wood production (Raddi et al., 2009).

Trees on coastal sites also often suffer from underground problems (e.g. root damage). This problem has become more common on sandy coasts throughout Mediterranean regions due to the filtering factor which limits the water retention capacity of the sandy soils of the coastal dunes where the availability of water could decrease abruptly during dry years. Accordingly, underground problems are associated with disturbed water and mineral uptake, leading to reduced wood production (Mc Laughlin et al., 2002).

A missing ring in a particular year should not endanger tree survival (Cherubini et al., 2002; Sass-Klassen et al., 2008). However, long-term disturbances of cambial activity often lead to physiological problems associated with disturbed water transport and reduced storage capacity of reserve assimilates (Bigler et al., 2004; Wunder et al., 2008).

The relationship between tree-ring index and precipitation from October to April shows that water availability is the main factor influencing tree growth of both pine species in Tunisia. These results are consistent with several previous dendroecological studies in Mediterranean regions (Raventos et al., 2001; El Khorchani, 2006; Campelo et al., 2007; Raddi et al., 2009; Mazza and Manetti, 2013) and showed that a large part of a tree ring is formed during the late winter and spring. These findings reflect the behavior of evergreen conifers that grow in regions with mild winters and are characterized by a photosynthetic activity in winter that produces carbohydrates for early wood formation in the following year (Kozlowski et al., 1991). The number of months that precipitation is positively correlated with growth is always less for trees growing near the shoreline than for those growing in distant stands. Thus, low amounts of precipitation over the past months in Tunisia, which is the only available freshwater, has reduced soil water content above the water table. The degree to which trees regulate water loss during drought may explain patterns of carbohydrate production and subsequent susceptibility to drought or biotic attack (McDowell et al., 2008). Stomatal responses to drought vary from drought avoidance, in which stomata close at a threshold water potential to minimize further transpiration, to drought tolerance, in which stomatal closure is less severe and transpiration continues at relatively high rates (McDowell et al., 2008).

The negative relationships with maximal temperatures show that the number of months that maximal temperature is correlated 

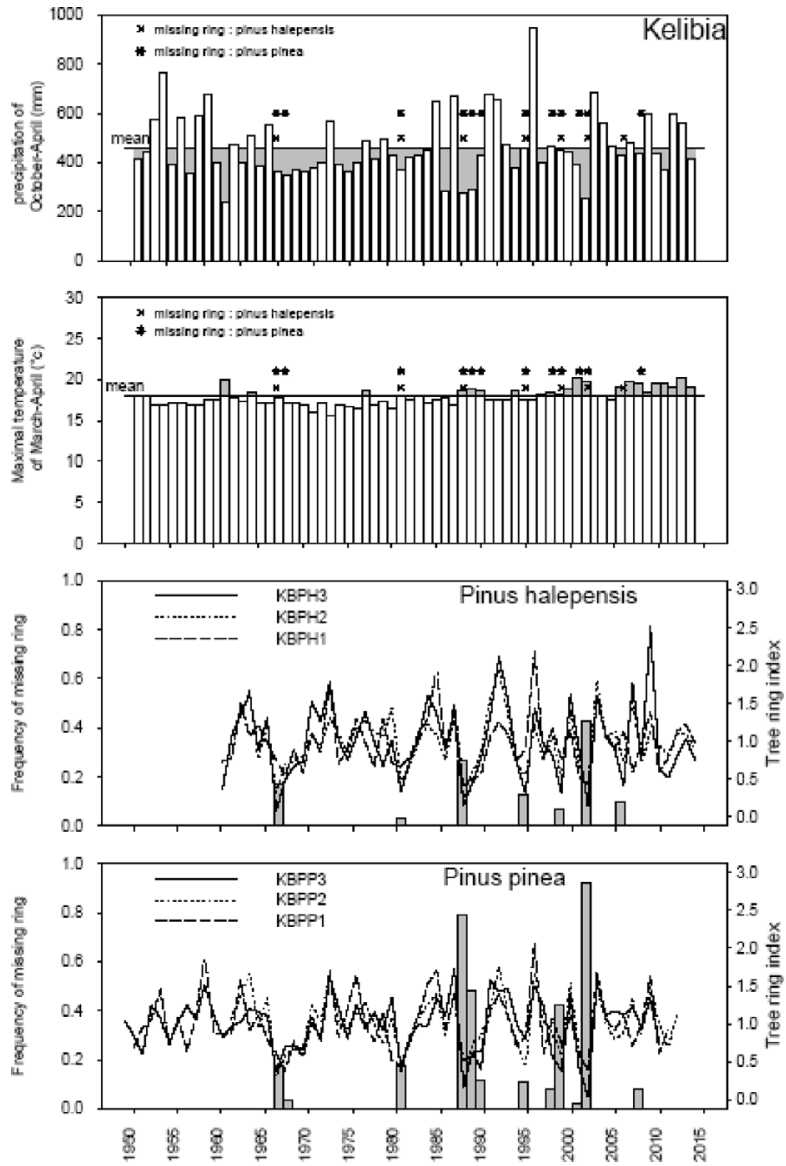
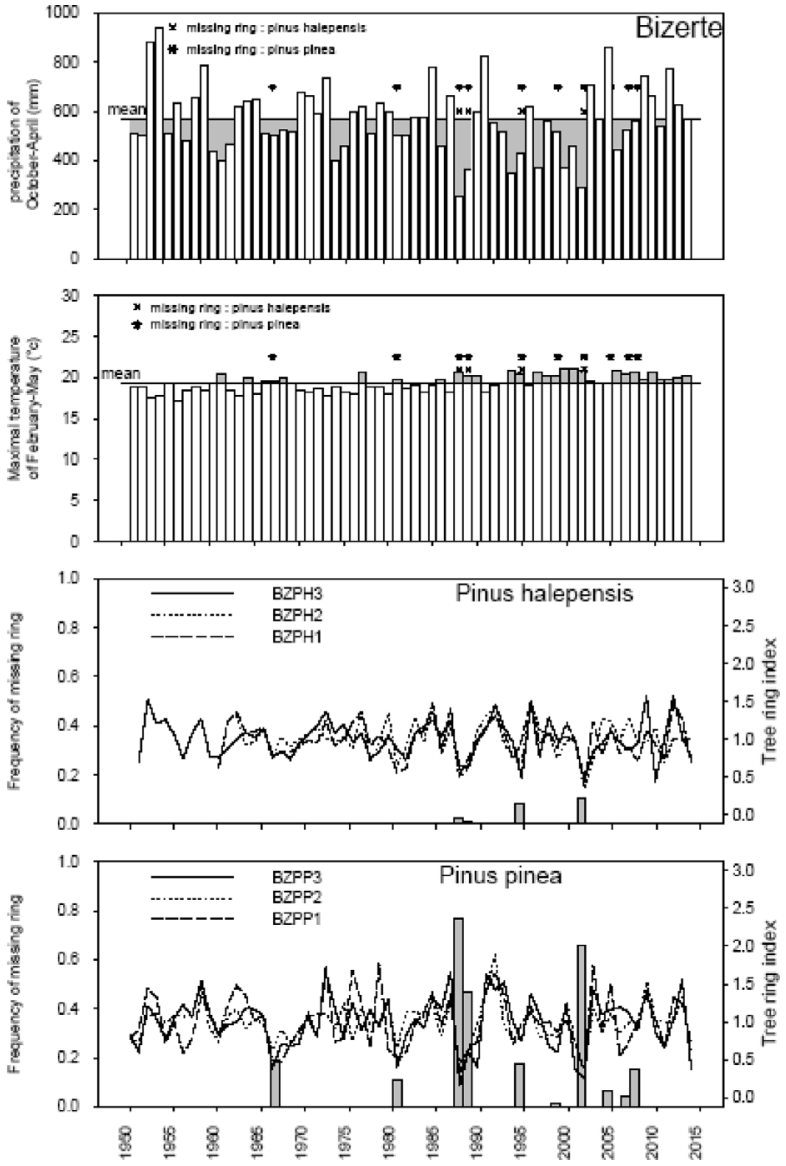

Fig. 5. Mixed graph for missing rings, temperature and precipitation based on the result of response function.

negatively with growth is always higher for trees growing near the shoreline ( 2 months) than for trees growing in distant stands ( 1 month). This observation could be interpreted by the possibility of intense water stress for trees growing near the shoreline. However, precipitation remains the primary explanatory variable of tree growth decline. High temperatures might also affect water shortage because of increased evapotranspiration and soil water evaporation (Campelo et al., 2006). Furthermore, recent research indicates that warmer temperatures alone can increase forest water stress, independent of the amount of precipitation (Barber et al., 2000). Moreover, on coastal sand dunes where water availability could suddenly decrease in dry years, the negative effect of maximal temperature on radial growth in the spring could accentuate the phenomenon of water stress (Aussenac, 1976; El Khorchani et al., 2007). Water availability still remains a factor more limiting than temperature. Thus, it might be the case that Pinus pinea, like other Mediterranean species (e.g. Pinus halepensis), responds by becoming increasingly dependent on moisture from deeper soil horizons that have not been exhausted in previous years (Sarris et al., 2007). In a study on the process based model shedding light on climate sensitivity of Mediterranean tree-ring width, conducted on Pinus halepensis from semi-arid areas in Tunisia, Touchan et al. (2012) showed that the average duration of the growing season is 191 days, and that on average soil moisture limits tree-ring growth for 128 days and temperature for 63 days in that 191-day window. Due to water deficiency and subsequent stomata closure, dryness causes a decrease in photosynthesis and consequently fewer carbohydrates are available for radial growth (Sitte et al., 1999).

The combination of response function, dendrochronological measurements and structural characteristics of Pinus halepensis and Pinus pinea stands has shown that distance from the shoreline influences environmental conditions. The closer the trees are to the shoreline, the more they are put under stress conditions. Among these stress conditions, drought can operate as a trigger ("inciting factor") that may ultimately lead to mortality or dieback in trees that are already under stress (by "predisposing factors" such as old age, poor site conditions and air pollution) and succumb to subsequent stem and root damage by biotic agents ("contributing factors" such as wood-boring insects and fungal pathogens) (Manion and Lachance, 1992).

Dieback of pine forests involves multiple interacting factors, ranging from particular sequences of climate stress and stand life histories to insect pests and diseases (Manion, 1981; Miao et al., 2009). Of the many factors of climate stress, drought is a concern affecting forests in coastal zones. This type of damage causes long-term degradation that may predispose trees to attack by pathogens and pests. Forests may become ecologically unstable, reducing their efficiency to protect coastal dunes and increasing forest fire risks due to the abundance of dry canopies.

\section{Conclusion}

The northeastern pine coastal woodland of Tunisia has great ecological and economic importance in protecting the soil from erosion and controlling water shortage. The major threats to the coastal landscapes of Tunisia, are common along the Mediterranean coastal zone, and related to uncontrolled development, urbanization, increasing national and international tourism and unplanned or over-exploitation of natural resources. Depletion and degradation of resources, including freshwater, forests and coastal areas, is a growing concern, as is pollution within the region itself (Vogiatzakos and Cassar, 2007). Our study indicates that Pinus pinea and Pinus halepensis on subhumid Mediterranean coastlines are growing under stress conditions when trees are close to the shoreline. These stress conditions are manifested 
by a negative effect on radial growth and structural characteristics of the trees, namely the development of the crown and the needles which can lead to conditions of dieback. Several climate models indicate that drought frequency and intensity are expected to increase in the Mediterranean basin (Giorgi and Lionello, 2008; Lelieveld et al., 2012; Ozturk et al., 2015). In sensitive areas such as the coastal dunes of Rimel and Menzel Belgacem, maximum temperature is significantly negative in late winter and spring, high precipitation from autumn of the previous year to mid-April of the current year has a significantly positive influence on tree-ring width. Long-term low precipitation and high temperature during these months in Tunisia influence the availability of water resources and cause drought stress. The higher water stress induced by an increase in air temperature and a decrease in rainfall for successive years could seriously reduce growth accompanied by an increased number of missing rings of the Mediterranean pine species, despite their drought-tolerant behavior. Such conditions trigger physiological disturbances in trees and predispose them to be attacked by pathogens and pests and thus accelerate their decline. The Pinus pinaster decline observed in recent years on northern coastal dunes of Tunisia could be the consequence of this imbalance caused by such factors (drought, sea spray...). Our results suggest that stands growing in stressed conditions need different management approaches in order to achieve sustainability.

\section{Acknowledgements}

Special thanks are due to Mr. Abdelaziz Kebaier Heah of the National Institute of Meteorology that supplied the climatic data used in this paper. Thanks are also addressed to Mr. Adel Sakouhi, Head of Afforestation and Soil Protection at the Regional Office of Agricultural Development (CRDA of Bizerte) that allowed sampling from their own areas. We also thank Mrs. Salima Bahri for her help in Statistical Analysis.

\section{References}

Allen, C.D., Macalady, A.K., Chenchouni, H., Bachelet, D., McDowell, N., Vennetier, M., Kitzberger, T., Rigling, A., Breshears, D.D., Hogg (Ted), E.H., Gonzalez, P., Fensham, R., Zhangm, Z., Castro, J., Demidova, N., Lim, J.H., Allard, G., Running, S.W., Semerci, A., Cobb, N., 2010. A global overview of drought and heat-induced tree mortality reveals emerging climate change risks for forests. For. Ecol. Manag. 259, 660-684.

Allen, C., 2009. Climate-induced Forest Dieback: an Escalating Global Phenomenon? http://www.fao.org/docrep/011/i0670e/i0670e10.htm.

Aloui, A., 2010. Changements climatiques en Tunisie: impacts sur les forêts. Atelier avec les décideurs et parties prenantes concernées1-2 juin 2010 à Rabat Maroc.

Aussenac, G., 1976. La sécheresse de 1976: influence de déficit hydrique sur la croissance des arbres forestiers. Rev. For. Fr. XXX (2), 103-113.

Barber, V.A., Juday, G.P., Finney, B.P., 2000. Reduced growth of Alaskan white spruce in the twentieth century from temperature-induced drought stress. Nature 405, $668-673$.

Barbero, M., Loisel, R., Quézel, P., Richardson, D.M., Romane, F., 1998. Pines of the mediterranean basin. In: Richardson, D.M. (Ed.), Ecology and Biogeography of Pinus. Cambridge University Press, pp. 153-170.

Ben Jamaâ M-L, Jerraya A, Lieutier F, 2000. Les scolytes ravageurs de pins en Tunisie. Ann INRGREF 2000. 6, 27-39.

Ben Jamaa, M.L., Sghaier, T., Mnara, S., Nouri, M., Sellemi, H., 2005. Le dépérissement du chêne liège dans la subéraie de Bellif (Tunisie): caractérisation et évaluation de son impact sur l'accroissement du Liège. IOBC WPRS Bull. 28, 17-24.

Ben Jamaa, M.L., Nouri, M., Mnara, M., Sellemi, H., Othmani, M., 2006a. Caractérisation du dépérissement du chêne-liège dans la subéraie de Bellif (Nord-Ouest) de la Tunisie. Ann. l'INRGREF (numero special) 125-137.

Ben Jamaa, M.L., Chaar, H., Brinsi, M., Nouri, M., 2006b. Impact des variations climatiques sur le dépérissement du chêne-liège (Quercus suber L.) dans la région d'Ain Draham. Ann. del'INRGREF (numero special) 138-153.

Bentouati, A., 2008. La situation du cèdre de l'Atlas en Algérie. Forêt Méditerranéenne 29, 203-209.

Bigler, C., Gričar, J., Bugmann, H., Čufer, K., 2004. Growth patterns as indicators of impending tree death in silver fir. For. Ecol. Manag. 199, 183-190.

Bigler, C., Braker, O.U., Bugmann, H., Dobbertin, M., Rigling, A., 2006. Drought as aninciting mortality factor in Scots pine stands of the Valais, Switzerland. Ecosystems 9, 330-343.

Boisvenue, C., Running, S.W., 2006. Impacts of climate change on natural forestproductivityevidence since the middle of the 20th century. Glob. Change Biol. 12, $1-21$.
Bonan, G.B., 2008. Forests and climate change: forcings, feedbacks, and the climatebenefits of forests. Science 320, 1444-1449.

Breda, N., Huc, R., Granier, A., Dreyer, E., 2006. Temperate forest trees and standsunder severe drought: a review of ecophysiological responses, adaptation processes and long-term consequences. Ann. For. Sci. 63, 625-644.

Bruun, P., 1988. The Bruun Rule of erosion by sea level rise: a discussion on large-scale two- and three-dimensional usages. J. Coast. Res. 4, 627-648.

Bussotti, F., Grossoni, P., Pantani, F., 1995. The role of marine salt and surfactants in the decline of Tyrrhenian coastal vegetation in Italy. Ann. For. Sci. 52, 251-261.

Bussotti, F., Bottacci, A., Grossoni, P., Mori, B., Tani, C., 1997. Cytological and structural changes in Pinus pinea L. needles following the application of an anionic surfactant. Plant Cell Environ. 20, 513-520.

Campelo, F., Nabais, C., Freitas, H., Gutiérrez, E., 2007. Climatic significance of tree-ring width and intra-annual density fluctuations in Pinus pinea from a dry Mediterranean area in Portugal. Ann. For. Sci. 64 (2), 229-238 10.105/forest:2006107.

Cherubini, P., Fontana, G., Rigling, D., Dobbertin, M., Brang, P., Innes, J., 2002. Tree-life history prior to death: two fungal root pathogens affect tree-rings differently. J. Ecol. 90, 850-939.

Cook, E.R., Kairiukstis, L.A., 1990. Methods of Dendrochronology. Applications in the Environmental Sciences. International Institute for Applied Systems Analysis. Kluwer Academic Publishers, Dordrecht 394 p.. http://dx.doi.org/10.1007/978-94-0157879-0.

Cook, E.R., Peters, K., 1981. The smoothing spline: a new approach to standardizing forest interior tree-ring width series for dendroclimatic studies. Tree- Ring Bull. 41, 45-53.

Cook, E.R., 1985. A Time Series Analysis Approach to Tree Ring Standardization. University of Arizona, AZ (PhD Dissertation) $171 \mathrm{pp}$.

Davidson-Arnott, R.G.D., 2005. Conceptual model of the effects of sea level rise on sandy coast. J. Coast. Res. 21, 1166-1172.

Delatour, C., 1990. Dépérissement des chênes et pathogènes Revue Forestière Français XLII 2-1990.

Diamantopouolos, J., Biel, C., Savé, R., 2000. Meccanismi di resistenza/sensibilità nei confronti dell aerosol marino inquinato nella vegetazione costiera della zona di Barcelona. In: Workshop on Danni Alla Vegetaione Costiera Ed Inquinamento Da Tensioattivi. Giardini Botanici Hanbury. 5 Ottobre.

EEA European Environment Agency, 2006. The Changing Faces of Europe's Coastal Areas. European Environment Agency, Copenhagen p. 112.

El Abidine, A.Z., 2003. Forest decline in Morocco: causes and control strategy. Science et changements planetaires. Sècheresse 14, 209-218.

El Ayeb, N., Hanchi, B., Garrec, J.P., Rejeb, N., 2004. Effets des embruns marins pollués sur les feuilles d'Acacia cyanophylla Lindl. et d'Eucalyptus gomphocephala Dc. du littoral tunisien. Ann. For. Sci. 61, 283-291.

El Khorchani A., Gadbin-Henry C., Bouzid S., Khaldi A., 2007. L'impact de la sécheresse sur la croissance de trois espèces forestières en Tunisie (Pinus halepensis Mill., Pinus pinea L. et Pinus pinaster Sol.). Sécheresse 18(2), 1-9.

El Khorchani A., Khaldi A., Nasr Z., 2013. Evolution des relations croissance-climat de trois espèces de pin en Kroumirie (Nord-Ouest de la Tunisie). Sécheresse 24 (T.A), 138-146.

El Khorchani, A., 2006. Approche Dendrochronologique De l'influence Des Changements Climatiques Sur La Productivité Des Forêts De Pin d'Alep (Pinus Halepensis Mill.) En Tunisie. Thèse De Doctorat. Université d'Aix-Marseille III, France (211p).

FAO, 2006. Global Forest Resources Assessment 2005-Progress towards sustainable forest management. FAO Forestry Paper No. 147. Rome.

Frattegiani, M., Mencuccini, M., Mercurio, R., Profili, W., 1994. Quantitative analysis of Stone pine (Pinus pinea L.) root system morphology and its relationship with water table and soil characters. Invest. Agrar. Fuera de Ser 3, 405-416.

Fritts, H.C., 1976. Tree Rings and Climate. Academic Press, New York. N.Y 567 PP.

Gadbin-Henry, C., 1994. Etude Dendroécologique De Pinus Pinea L. Aspects méthodologiques. Thèse De Doctorat. Université d'Aix-Marseille III, France 80 p.

Garrec, J.P., 1994. Les dépérissements littoraux d'arbres forestiers. Rev. For. Fr. 46, 454-457.

Gellini, R., Pantani, F., Grossoni, P., 1986. Colloque International d'Ecologie littorale méditerranéenne. Société d'Ecologie 42 p.

Giorgi, F., Lionello, P., 2008. Climate change projections for the mediterranean region. Glob. Planet. Change 63, 90-104.

Grissino-Mayer, H.D., 2001. Evaluating crossdating accuracy: a manual and tutorial for the computer program COFECHA. Tree-Ring Res. 57 (2), 205-221.

Guiot, J., Goeury, C., 1996. PPPBASE, software for statistica analysis of paleoecology data. Dendrochronologia 14, 295-300.

Guiot, J., 1991. The boostrapped response function. Tree-Ring Bull. 51, 39-41.

Hasnaoui, F., Rjeibi, N., Chaabane, A., Yacoubi, W., Hasnaoui, B., 2005. Contribution à l'étude du dépérissement du chêne-liège dans la forêt de Tabarka: relations possibles entre nutriments et état sanitaire de l'arbre. IOBC/WPRS Bull. 28 (8), 20.

Henderson, J.P., Grissino-Mayer, H.D., 2009. Climate -tree growth relationships of longleaf pine (Pinus palustris mill.) in the southeastern Coastal Plain, USA. Dendrochronologia 27, 31-43.

Holmes, R.L., Adams, R.K., Fritts, H.C., 1986. Treeing Chronologies of Western North America: California, Eastern Oregon and Northern Great Basin, with Procedures Used in the Chronology Development Work, Including User Manuals for Computer Programs COFECHA and ARSTAN. Laboratory of Tree-Ring Research, University of Arizona, Tucon Chronology Series VI.

Holmes, R.L., 1983. Computer-assisted quality control in tree ring dating and measurement. Tree-Ring Bull. 43, 67-78.

Intergovernmental Panel on Climate Change, 2007. Climate Change 2007. Impacts Adaptation and Vulnerability. Cambridge University Press, Cambridge, UK, pp. 1000.

IPCC AR5 WGII, 2014. Fifth Assessment Report - Impacts, Adaptation and Vulnerability. http://www.ipcc.ch/report/ar5/wg2/. 
Lelieveld, J., Hadjinicolaou, P., Kostopoulou, E., Chenoweth, J., Giannakopoulos, C., Hannides, C., Lange, M.A., El Maayar, M., Tanarthe, M., Tyrlis, E., Xoplaki, E., 2012. Climate change and impacts in the eastern Mediterranean and the Middle East. Clim. Change 114, 667-687.

Manion, P.D., Lachance, D., 1992. Forest Decline Concepts. APS Press, St. Paul, MN $249 \mathrm{pp}$.

Manion, P.D., 1981. Decline diseases of complex biotic and abiotic origin. In: Manion, P.D. (Ed.), Tree Disease Concepts. Prentice-Hall, Englewood Cliffs, NJ, pp. 324-339.

Mazza, G., Manetti, M.C., 2013. Growt rate and climate responses of Pinus pinea L. in Italien oastal stands over the last centry. Clim. Change 121, 713-725.

Mazzoleni, S., di Pasquale, G., Mulligan, M., di Martino, P., Rego, F. (Eds.), 2004. Recent Dynamics of the Mediterranean Vegetation and Landscape. John Wiley \& Sons, Chichester 306pp.

Mc Laughlin, S.B., Shortle, W.C., Smith, K.T., 2002. Dendroecological alications in air pollution and environmental chemistry: research needs. Dendrochronologia 20, 133-157.

McDowell, N., Pockman, W.T., Allen, C.D., Breshears, D.D., Cobb, N., Kolb, T., Sperry, J., West, A., Williams, D., Yepez, E.A., 2008. Mechanisms of plant survival and mortality during drought: why do some plants survive while others succumb to drought? Tansley review. New Phytol. 178, 719-739.

Miao, S.L., Zou, C.B., Breshears, D.D., 2009. Vegetation responses to extreme hydrological events: sequence matters. Am. Nat. 173, 113-118.

Nicolotti, G., Rettori, A., Paoletti, E., Gullino, M.L., 2005. Morphological and physiological damage by surfactant-polluted sea spray on Pinus pinea and Pinus halepensis. Environ. Monit. Assess. 105, 175-191.

Novak, K., De Luis, M., Cufar, K., Raventós, J., 2011. Frequency and variability of missing tree rings along the stems of Pinus halepensis and Pinus pinea from a semiarid site in SE Spain. J. Arid Environ. 75, 494-498.

Office National des Forêts, Institut pour le développement forestier, 2010. Guide de gestion des forêts en crise sanitaire. ISBN: 978-2-84207-344-2.

Ozturk, T., Ceber, Z.P., Türkeş, M., Kurnaz, M.L., 2015. Projections of climate change in the Mediterranean Basin by using downscaled global climate model outputs. Int. J. Climatol. 35, 4276-4292. http://dx.doi.org/10.1002/joc.4285.

Parker, K.C., Jensen, C., Parker, A.J., 2014. The growth response of slash pine (Pinus elliottii) to climate in the Georgia Coastal Plain. Dendrochronologia 32, 127-136.

Raddi, S., Cherubini, P., Lauteri, M., Magnani, F., 2009. The impact of sea erosion on coastal Pinus pinea stands: a diachronic analysis combining tree-rings and ecological markers. For. Ecol. Manag. 257, 773-781.

Raventós, J., De Luis, M., Gras, M.J., Cufar, K., González-Hidago, J.C., Bonet, A., Sánchez,
J.R., 2001. Growth of Pinus pinea and Pinus halepensis as affected by dryness, marine spray and land use changes in a Mediterranean semiarid ecosystem. Dendrochronologia 19, 211-220.

Rettori, A., Paoletti, E., Nicolotti, G., Gullino, M.L., 2005. Ecophysiological responses of Mediterranean pines to simulated sea aerosol polluted with an anionic surfactant: prospects for biomonitoring. Ann. For. Sci. 62, 351-360.

Rinn, F., 2003. TSAP-Win: Time Series Analysis and Presentation for Dendrochronology and Related Applications. Version 0.55 User reference, Heidelberg, Germany (http:// www.rimatech.com).

Sarris, D., Christoduolakis, D., Körner, C., 2007. Recent decline in precipitation and tree growth in the eastern Mediterranean. Glob. Change Biol. 106 (2), 203-223.

Sass_Klassen, U., Couralet, C., Sale, Y., Sterck, F.J., 2008. Juniper from Ethiopia contains a large-scale precipitation signal. Int. J. Plant Sci. 169, 1057-1068.

Serre, F., 1973. Contribution à l'étude Dendroclimatologique Du Pin d'Alep (Pinus Halepensis Mill.). Thèse De Doctorat. Université d'Aix-Marseille III, France 236 p.

Sitte, P., Zeiegler, H., Ehrendorfer, F., Bresinsky, A., 1999. Strasburg- Lehrbuch Der Botanik. Spektrum Akademischer Verlag, Heidelberg, pp. 1030.

Spittlehouse, D., 2005. For. Chron. 81, 691-695.

Touchan, R., Anchukaitis, K.J., Meko, D.M., Attalah, S., Baisan, C., Aloui, A., 2008. Long term context for recent drought in northwestern Africa. Geophys. Res. Lett. 35, L13705.

Touchan, R., Shishov, V.V., Meko, D.M., Nouiri, I., Grache, A., 2012. Process based model sheds light on climate sensitivity of Mediterranean tree-ring width. Biogeosciences 9 965-972.

Vogiatzakos, I.N., Cassar, L.F., 2007. Coastal Landscape of Tunisia- A Proposed Landscape Character Assesment. Split Priority Actions Program.

Wunder, J., Reineking, B., Bigler, C., Bugmann, H., 2008. Predicting tree mortality from growth data: how virtual ecologists can help real ecologists. J. Ecol. 96, 174-187.

de Luis, M., González-Hidalgo, J.C., Longares, L.A., Stepanek, P., 2009. a. Seasonal precipitation trends in the Mediterranean lberian Peninula in second half of 20 th century. Int. J. Climatol. 29, 1312-1323.

De Luis, M., Brunetti, M., González-Hidalgo, J.C., Longares, L.A., Martín-Vide, J., 2010. Changes in seasonal precipitation in the Iberian Peninsula during 1946-2005. Glob. Planet. Change 74, 27-33.

van Mantgem, P.J., Stephenson, N.L., Byrne, J.C., Daniels, L.D., Franklin, J.F., Fulé, P.Z. Harmon, M.E., Larson, A.J., Smith, J.M., Taylor, A.H., Veblen, T.T., 2009. Widespreadincrease of tree mortality rates in the western United States. Science 323, 521-524. 